\title{
THE DEPENDENCE OF THE ELECTRODYNAMIC CHARACTERISTICS OF THE MICROSTRIP PHASED ARRAY SUBARRAY ON THE METHOD OF POWER SUPPLY
}

\section{Evgeny V. Ukhanov,} Joint-stock Company "Scientific research institute" Kulon", Moscow, Russia, searif@ya.ru

Roman V. Terekhin, Joint-stock Company "Scientific research institute" Kulon", Moscow, Russia, terekhin.r@gmail.com

Sofia R. Kosichkina, Joint-stock Company "Scientific research institute" Kulon", Moscow, Russia, sofkos@yandex.ru

\section{Konstantin V. Strygin,}

Joint-stock Company "Scientific research institute" Kulon", Moscow, Russia, kstrygin@gmail.com

Ekaterina V. Syukieva, Joint-stock Company "Scientific research institute" Kulon", Moscow, Russia, eksyukieva@gmail.com
DOI: 10.36724/2072-8735-202|-|5-4-57-64

Manuscript received 14 December 2020; Accepted 26 January 2021
Keywords: phased array, subarray, rectangular emitter, emissivity, resonant frequency, bandwidth

\begin{abstract}
Microwave technology in microstrip design is widely used in various antenna systems. The active use of phased array (PA) of this type makes developers around the world search for various options of its construction. To improve individual characteristics, in particular, expand the scanning angle, as well as optimize the configuration of the excitation of the PA, they use subarrays that combine a given number of elements of the entire array. In this paper, we considered various options for constructing microstrip PA subarrays made on a homogeneous substrate from a high-frequency laminate GIL_GML 1000, in particular, various methods for their excitation. Using modern, accurate 3D electrodynamic modeling environment and HF device analysis, we studied changes in the electrodynamic characteristics of the simulation model of a multi-element microstrip PA subarray, depending on how the excitation is organized. This article discusses three simulation models of subarrays for microstrip PA with various options for their excitation. All subarrays have a radiation pattern of a special shape. After calculating the main characteristics, the issue of the most preferred organization of subarray power supply for the developed PA was solved. It is shown that in practice, the study of parameters and decision-making on the design of complex microwave devices, possibly without expensive field modeling.
\end{abstract}

Information about authors:

Evgeny V. Ukhanov, department head, Joint-stock Company "Scientific research institute" Kulon", Moscow, Russia

Roman V. Terekhin, senior engineer, Joint-stock Company "Scientific research institute" Kulon", Moscow, Russia

Sofia R. Kosichkina, engineer, Joint-stock Company "Scientific research institute" Kulon", Moscow, Russia

Konstantin V. Strygin, engineer, Joint-stock Company "Scientific research institute" Kulon", Moscow, Russia

Ekaterina V. Syukieva, engineer, Joint-stock Company "Scientific research institute" Kulon", engineer, Moscow, Russia

Для цитирования:

Уханов Е.В., Терехин Р.В., Косичкина С.Р., Стрыгин К.В., Сюкиева Е.В. Зависимость электродинамических характеристик подрешетки микрополосковой ФАР от способа подключения питания // Т-Сomm: Телекоммуникации и транспорт. 202।. Том I5. №4. С. 57-64.

For citation:

Ukhanov E.V., Terekhin RV., Kosichkina S.R., Strygin K.V., Syukieva E.V. (202I)The dependence of the electrodynamic characteristics of the microstrip phased array subarray on the method of power supply. T-Comm, vol. I5, no.4, pp. 5764. (in Russian) 
Microwave technology in microstrip design is widely used in various antenna systems. The active use of phased array (PA) of this type makes developers around the world search for various options of its construction. To improve individual characteristics, in particular, expand the scanning angle, as well as optimize the configuration of the excitation of the PA, they use subarrays that combine a given number of elements of the entire array. In this paper, we considered various options for constructing microstrip PA subarrays made on a homogeneous substrate from a highfrequency laminate GIL_GML 1000, in particular, various methods for their excitation. Using modern, accurate 3D electrodynamic modeling environment and HF device analysis, we studied changes in the electrodynamic characteristics of the simulation model of a multi-element microstrip PA subarray, depending on how the excitation is organized. For each simulation model, the results of calculating the reflection coefficient (parameter S11) are presented depending on the frequency range, the gain is calculated in 3D format, as well as in the polar coordinate system. Table 1 presents a comparative analysis of the main characteristics of the subarray with three power supply options calculated using microwave modeling in the EMPro environment using the FDTD method. The main advantages and disadvantages of each option are shown on the corresponding simulation model. As a result, it was concluded that in such parameters as: gain, efficiency, and VSWR, the multi-element subarray with the power supply connected to its center has the best characteristics (Figure 1, a). The most broadband is the subarray with power supply connected through the shank, brought to the center (Figure 1, b).

Currently, the most frequently used various purposed and based antenna systems (AS) are phased arrays or active electronically scanned arrays (AESA). However, the element base used in the construction of antenna arrays in the form of slot antennas, horns, open ends of waveguides, etc., is often quite cumbersome and expensive. The requirements of compactness, low weight and relatively low price with acceptable characteristics are sufficiently met by microstrip electronically scanned arrays (AESA). For the formation of a radiation pattern of a given shape, the expansion of the scanning angle with the least gain loss, as well as the optimization of the configuration of the array when organizing its excitation, subarrays of several microstrip emitters are often used as a separate element of the PA. However, during their design and production, many questions arise, the main of which is the organization of the excitation of a given AS, as well as their characteristics, such as: gain, efficiency and standing wave voltage coefficient (VSWR). Since the electrodynamic characteristics of the PAs as a whole depend on the characteristics of the subarrays, a detailed study of the latter arises.

However, the production of the model of the same subarray, with various types of power supply, is a rather laborious process, consuming human, temporal and financial resources. To minimize the above costs, it is advisable to use computer simulation electrodynamic models made using special programs and allowing necessary AS characteristics evaluation. The work of such software products is based on the numerical solution of Maxwell's equations in integral or differential form.

This article will consider the PAR subarray, consisting of eight elements with various types of organization of excitation. The simulation model characteristics calculation, both of an individual element of the subarray and of the entire microstrip PA subarray, was performed using a modern, accurate 3D electrodynamic modeling and analysis environment for EMPro RF devices.

At the first stage, a simulation model of an individual microstrip emitter was created. As a separate element of the microstrip PA subarray, a rectangular emitter on a homogeneous substrate was chosen, described in [1]. The type of emitter simulation model and its geometric dimensions are presented in Figure 1 . The simulation model of the substrate of a single emitter is a square with the geometric dimensions of the sides $\mathrm{L} 1=\mathrm{L} 2=93 \mathrm{~mm}$.

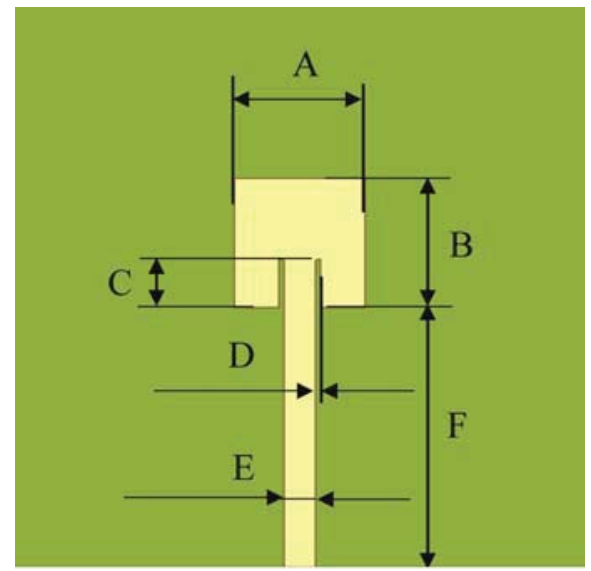

Figure 1. Simulation model of a single emitter with its geometric dimensions

A separate element of the microstrip PA subarray is a square emitter with sides $A=15.2 \mathrm{~mm}$ and $\mathrm{B}=15.2 \mathrm{~mm}$, which is fed by a microstrip line with a length of $\mathrm{F}=30.4 \mathrm{~mm}$ and a width of $\mathrm{E}=3.8 \mathrm{~mm}$. The wave impedance of the entire antenna is also controlled by symmetrical slots of the emitter with dimensions $\mathrm{C}=5.7 \mathrm{~mm}$ and $\mathrm{D}=0.63 \mathrm{~mm}$.

For rectangular emitter (shown in Figure 1) characteristics research, its excitation was carried out using a simulation model of a pin located in the lower part of the shank of a microstrip emitter. The power supply model consists of a voltage source and a $50 \mathrm{ohm}$ resistor connected in series between the microstrip print and the ground plane.

The signal excitation model is a Gaussian pulse. In the time domain, it is presented in Figure 2. In this paper, the presented model of the excitation signal will be further used for all studied models of the PA subarrays.

When choosing a dielectric substrate, we used the review of microwave dielectrics used in microstrip antennas presented in $[2,3]$. As a result, for the study, a simulation model of an individual emitter was chosen, made on a homogeneous substrate from a high-frequency laminate GIL_GML 1000 with parameters $(\varepsilon=(3.05-j 0.004) \varepsilon 0)$ and a thickness $S=1.524 \mathrm{~mm}$.

Consider some characteristics of the simulation model of an individual emitter shown in Figure 1.

The results of calculating the reflection coefficient (parameter S11) for the simulation model of an individual element of the microstrip headlamp sublattice on a GIL_GML 1000 substrate are presented in Figure 3. The resonant frequency of this emitter is Fres $=5.39 \mathrm{GHz}$. 


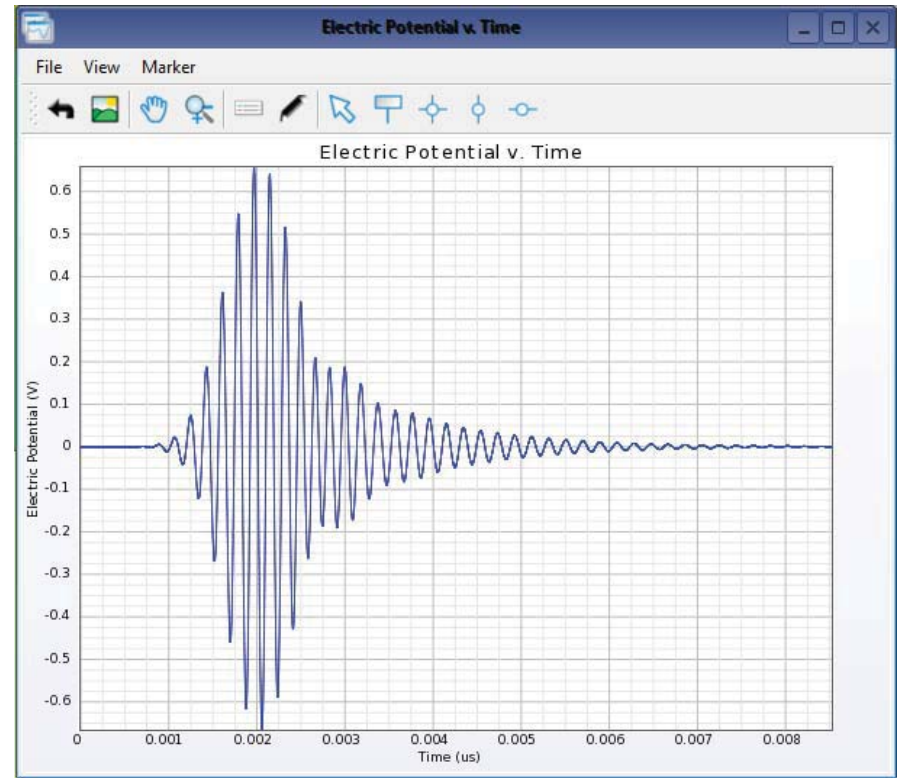

Figure 2. Model of the excitation signal of the studied antennas

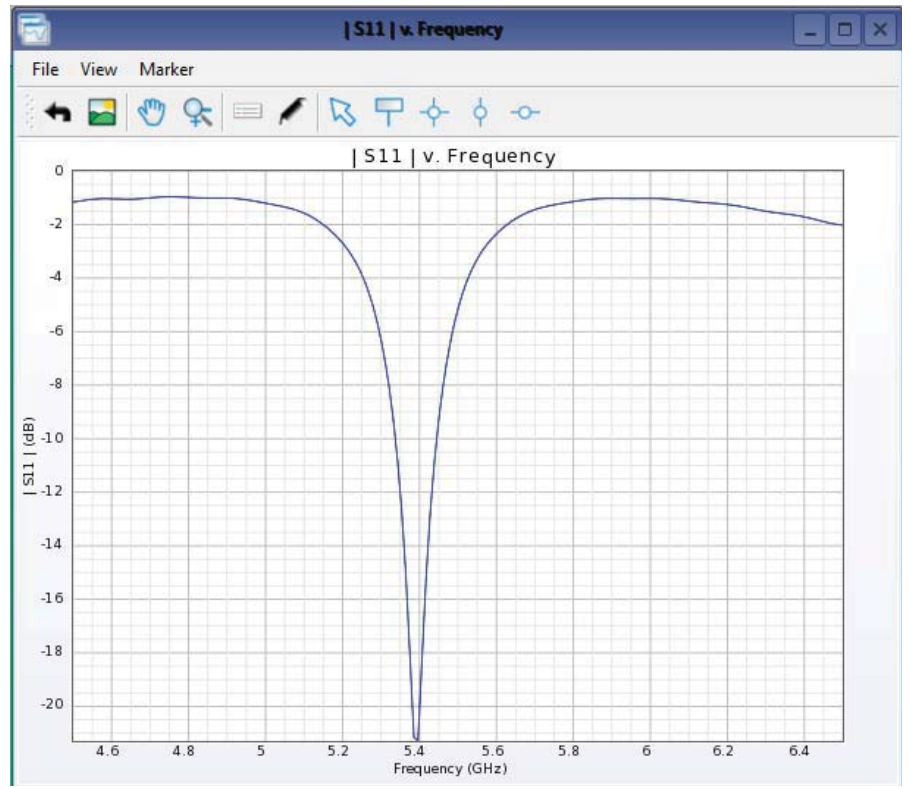

Figure 3. The calculated S11 is the parameter of the simulation model of an individual element of the microstrip PA subarray on a GIL_GML 1000 substrate

Figure 3 shows the calculated frequency dependence of the parameter S11 for the frequency range from $4.5 \mathrm{GHz}$ to $6.5 \mathrm{GHz}$. These results are summarized in table 1 , as the minimum (Fmin) and maximum (Fmax) frequency values at a reflection coefficient S11 $=-10 \mathrm{~dB}$. The difference between Fmax and Fmin determines the bandwidth of the simulation model of an individual subarray element of the microstrip PA at S11 $=-10 \mathrm{~dB}$.
Table 1

\begin{tabular}{|c|c|c|c|c|}
\hline Substrate type & Fmin, GHz & Fmax, GHz & Fres., GHz & $\Delta$ Fmax, GHz \\
\hline GIL_GML 1000 & 5,34 & 5,44 & 5,39 & 0,10 \\
\hline
\end{tabular}

Table 1 presents the absolute values of the results of calculating the parameter S11 $=-10 \mathrm{~dB}$ for a simulation model of an individual subarray element of a microstrip PA with a uniform substrate GIL_GML 1000.

Figure 4 shows the calculated frequency dependence of the power at the input of the simulation model of an individual element of the microstrip PA on a GIL_GML 1000 substrate in the range from $4.5 \mathrm{GHz}$ to $6.5 \mathrm{GHz}$, excluding losses.

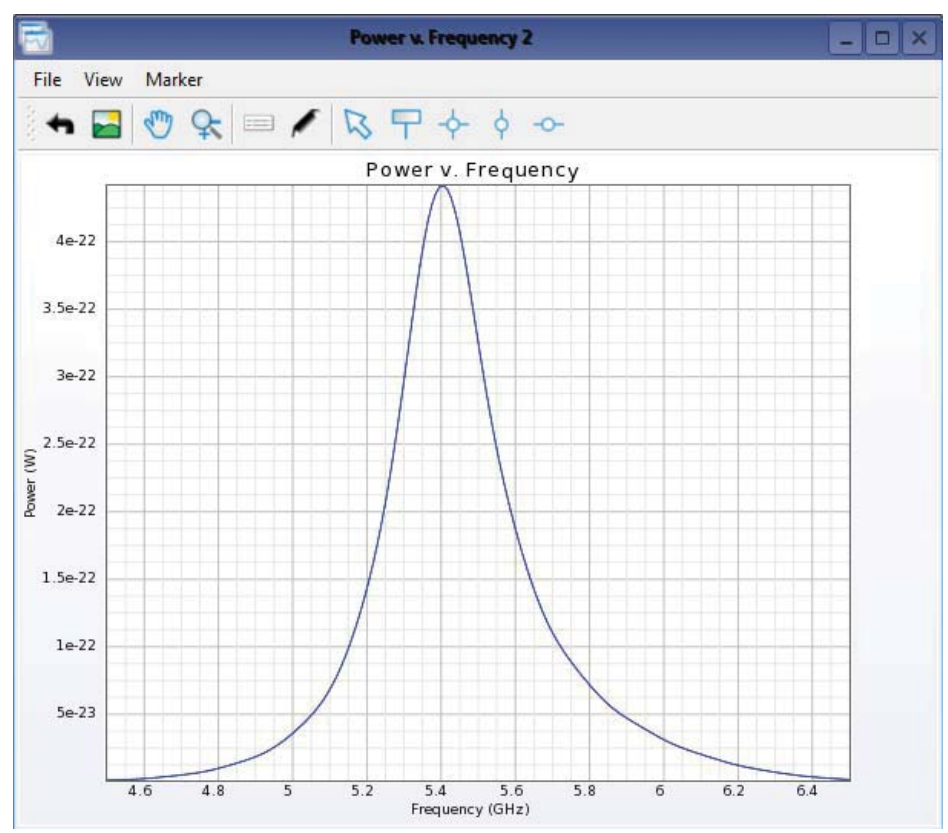

Figure 4. Frequency dependence of power at the input of a simulation model of an individual element of a microstrip headlamp on a GIL_GML 1000 substrate

Figure 5a,b shows the calculated value of the gain of an individual element of the microstrip PA subarray on the GIL_GML 1000 substrate in $3 \mathrm{D}$.

The gain with perfect matching of the individual emitter of the microstrip PA subarray on the GIL_GML 1000 substrate in the polar coordinate system is shown in Figure 6.

Since the elements of the microstrip PA considered above are weakly directional, a polar coordinate system is selected to display the radiation pattern in $2 \mathrm{D}$ format. The advantage of beam image in this system is a visual representation of electromagnetic energy spatial distribution emitted by the antenna. 


\section{ELECTRONICS. RADIO ENGINEERING}

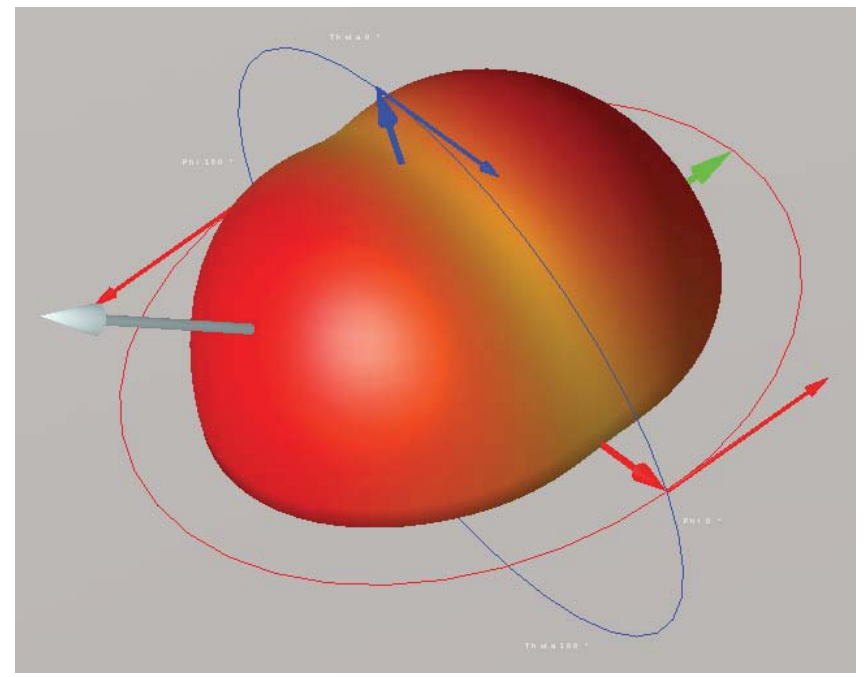

a)

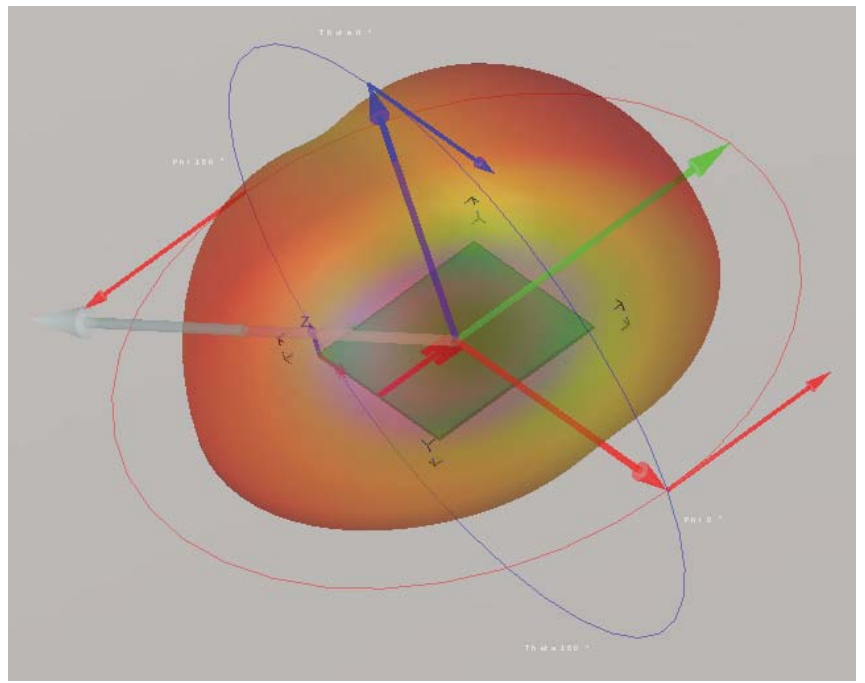

b)

Figure 5. The calculated gain with perfect matching for the model of microstrip PA subarray individual element on a GIL_GML 1000 substrate in 3D format

Theta $=\left[0^{\circ}, 180^{\circ}\right]$; Phi $=\left[0^{\circ}, 360^{\circ}\right]$. The white arrow indicates the direction of the main lobe Theta $=50^{\circ}$; Phi $=90^{\circ}$.

As a result of simulation, the following characteristics of microstrip PA subarray individual emitter obtained on the GIL_GML 1000 substrate were obtained:
- maximum gain
- $2.153 \mathrm{~dB}$;
- net input power
$-0.0005834 \mathrm{~W}$;
$-0.0002304 \mathrm{~W}$;
- Efficiency - 39.5\%.

At the next stage, a simulation model of the microstrip PA subarray was developed. Figure 7 a, b and c shows a subarray consisting of eight elements with various options for connecting a power source. The array elements are located in the nodes of the rectangular grid, the distance between which along the $\mathrm{X}$ and $\mathrm{Y}$ axes was calculated according to the technique presented in $[4,5]$ :

where:

$$
\frac{d_{x}}{\lambda} \leq \frac{1}{1+\sin a_{0}} \quad \frac{d_{y}}{\lambda} \leq \frac{1}{1+\sin \beta_{0}}
$$

$\sin a_{0}=\sin \Theta_{c k} \cos \varphi_{c k}$

$\sin \beta_{0}=\sin \Theta_{c k} \sin \varphi_{c k}$.

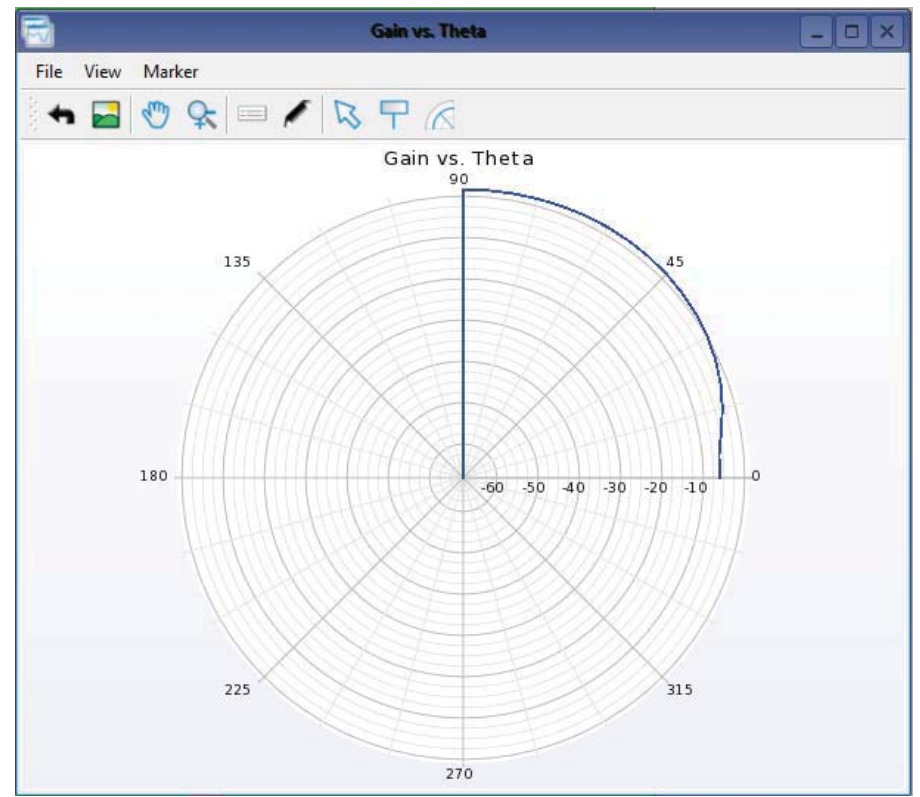

Figure 6. Gain with perfect matching of microstrip PA subarray individual emitter, on a GIL_GML 1000 substrate in a polar coordinate system

For this study, a subarray simulation model made on a homogeneous substrate from a high-frequency laminate GIL_GML 1000 with parameters $(\varepsilon=(3.05-\mathrm{j} 0.004) \varepsilon 0)$ and a thickness of $\mathrm{S}=1.524 \mathrm{~mm}$ and dimensions of $\mathrm{X}=195 \mathrm{~mm}$ and $\mathrm{Y}=186 \mathrm{~mm}$ was chosen. Parameters were calculated in the frequency band $\Delta \mathrm{F}=(4.5-6.5) \mathrm{GHz}$. The excitation signal model is shown in Figure 2.

Figure 8 a, b and c shows the calculated reflection coefficient (parameter S11) for each simulation model of the microstrip PA subarray of eight emitters, shown in Figure 7 a, b and c, respectively. Figure 8a shows that in the subarray in a given frequency range, two working frequencies can be distinguished. The first resonant frequency of this microstrip subarray is Fres $1=5.445$ $\mathrm{GHz}$ and Fres2 $=6.195 \mathrm{GHz}$ - the fundamental frequency of the array itself. Figure 8b shows that for this subarray, in the considered frequency range, two working frequencies can also be distinguished.

The first resonant frequency is Fres1 $=5.4375 \mathrm{GHz}$, and the second Fres $2=6.175 \mathrm{GHz}$ is the fundamental frequency of the array itself. From Figure 8, it can be seen that for this subarray, three operating frequencies can be distinguished in the considered frequency range. The first resonant frequency is Fres1 $=5.45 \mathrm{GHz}$, the second Fres2 $=5.87 \mathrm{GHz}$ (spurious excitation frequency) and the third Fres $3=6.2 \mathrm{GHz}$ is the main resonant frequency of the array itself.

Figure 9a, b and c shows the calculated gain with perfect matching, in 3D format, for each simulation model of the microstrip PA subarray of eight emitters, shown in Figure 7 a, b and c, respectively. Figure $10 \mathrm{a}, \mathrm{b}$ and c, in 2D format, shows the gain calculated in steps of $5^{\circ}$ with perfect matching, in the polar coordinate system, for each simulation model of the microstrip PA subarray of eight emitters, shown in Figure 7 a, b and c, respectively. 


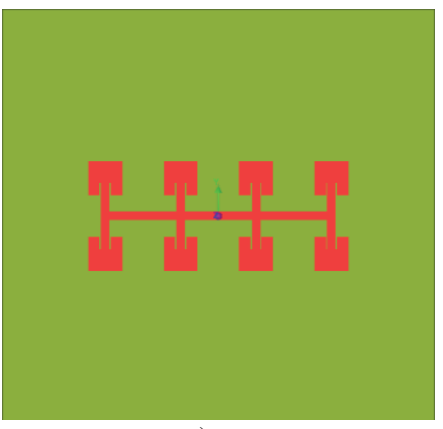

a)
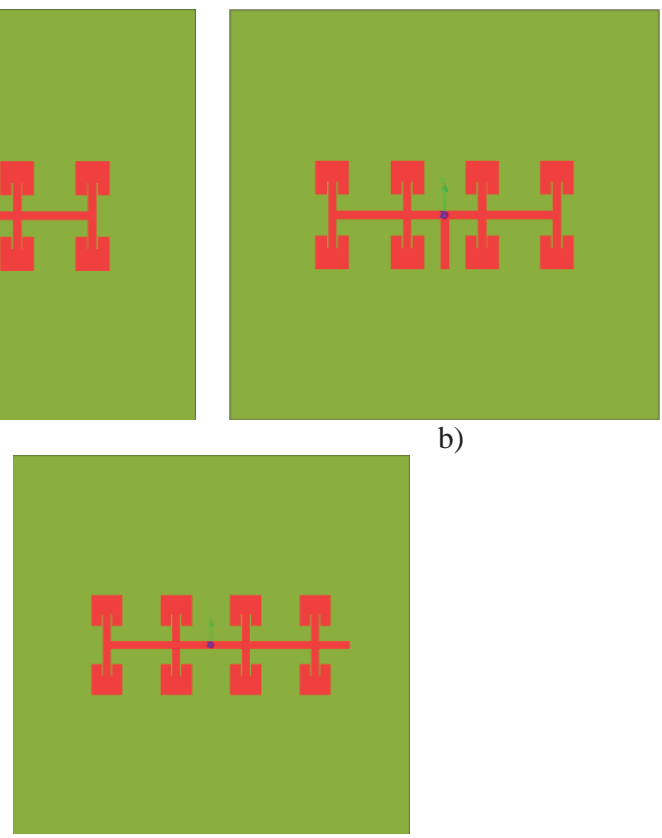

c)

Figure 7. Subarray, consisting of eight elements, with power connection: a) - in the center of the subarray; b) - through the shank, brought to the center of the subarray; c) - through the shank, brought up on the side of the subarray

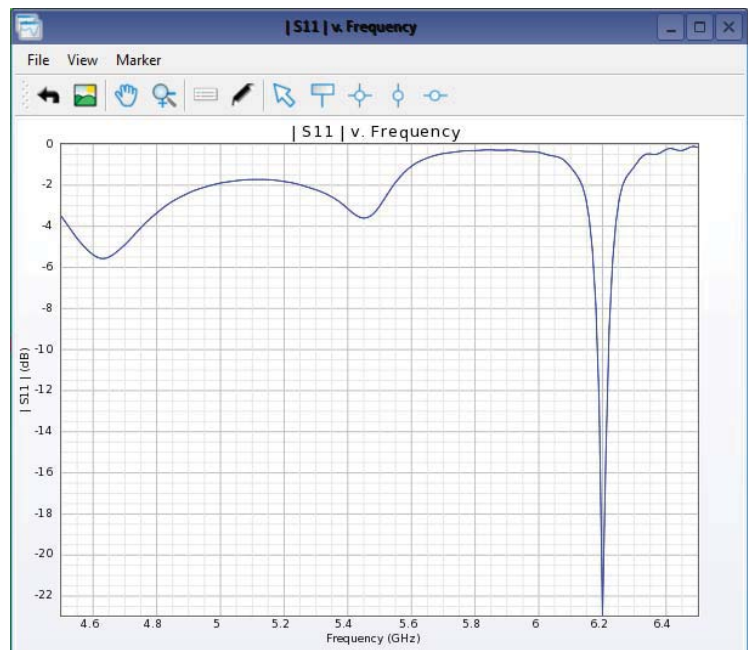

a)

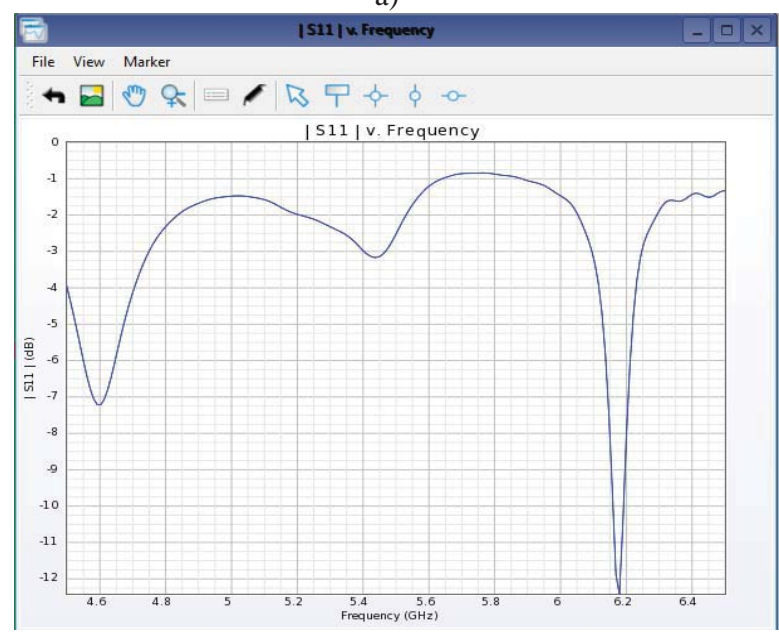

b)

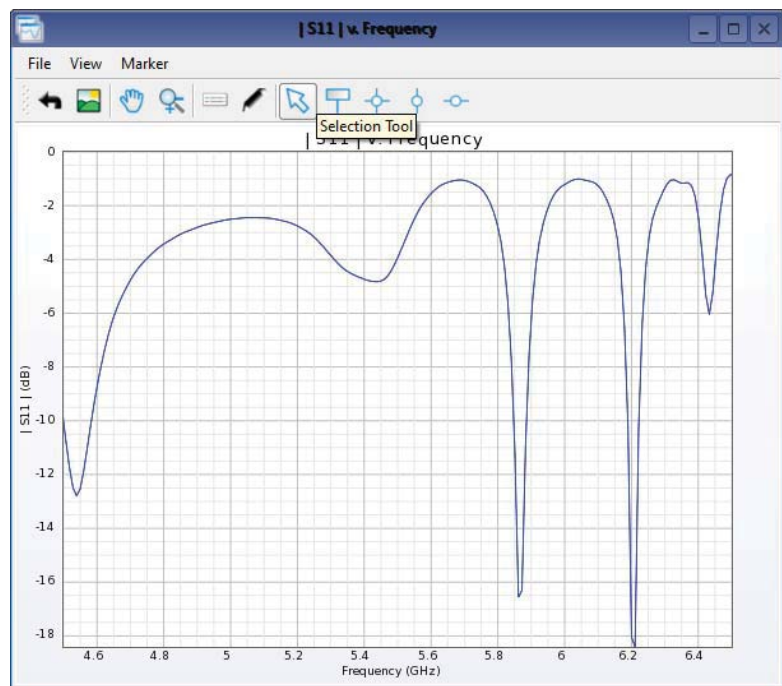

c)

Figure 8. Calculated S11 - parameter of microstrip subarray of eight emitters simulation model, with power connection: a) in the center of the subarray; b) - through the shank, brought to the center of the subarray; c) - through the shank, brought up on the side of the subarray

The main calculated characteristics are summarized in table 2 .

Table 2

\begin{tabular}{|l|c|c|c|c|c|c|c|}
\hline $\begin{array}{l}\text { Type of } \\
\text { subarray with } \\
\text { power con- } \\
\text { nection vari- } \\
\text { ants }\end{array}$ & $\begin{array}{c}\text { Gain, } \\
\mathrm{dB}\end{array}$ & $\begin{array}{c}\text { Input } \\
\text { Power, } \\
\mathrm{mW}\end{array}$ & $\begin{array}{c}\text { Output } \\
\text { Power, } \\
\mathrm{mW}\end{array}$ & $\begin{array}{c}\text { Efficiency, } \\
\%\end{array}$ & VSWR & $\begin{array}{c}\mathrm{fr}, \\
\mathrm{GHz}\end{array}$ & $\begin{array}{c}\Delta \mathrm{F}, \\
\mathrm{GHz}\end{array}$ \\
\hline $\begin{array}{l}\text { in the center } \\
\text { of the } \\
\text { subarray }\end{array}$ & 8,28 & 1,39 & 0,81 & 58,52 & 1,13 & 6,2 & 0,1 \\
\hline $\begin{array}{l}\text { through the } \\
\text { shank, } \\
\text { brought to } \\
\text { the center of } \\
\text { the subarray }\end{array}$ & 7,45 & 1,5 & 0,72 & 48,13 & 1,625 & 6,18 & 0,15 \\
\hline $\begin{array}{l}\text { through the } \\
\text { shank, } \\
\text { brought up } \\
\text { on the side of } \\
\text { the subarray }\end{array}$ & 7,22 & 2,25 & 1,23 & 54,73 & 1,275 & 6,21 & 0,1 \\
\hline
\end{tabular}

From the presented characteristics and graphs, we draw some conclusions about the parameters of the considered subarrays. From Figures 3 and 4, we can view the radiation pattern and gain of each of the subarrays. In Figure 3, a - Theta $=\left[0^{\circ}, 180^{\circ}\right]$; Phi $=\left[0^{\circ}, 360^{\circ}\right]$, the white arrow indicates the direction of the main lobe Theta $=65^{\circ}$; Phi $=90^{\circ}$. In figure $3, \mathrm{~b}-$ Theta $=\left[0^{\circ}, 180^{\circ}\right]$; hi $=\left[0^{\circ}, 360^{\circ}\right]$, a white arrow indicates the direction of the main lobe Theta $=70^{\circ}$; Phi $=90^{\circ}$. In Figure 3, c - Theta $=\left[0^{\circ}, 180^{\circ}\right]$; Phi $=\left[0^{\circ}, 360^{\circ}\right]$, the white arrow indicates the direction of the main lobe Theta $=65^{\circ}$; Phi $=80^{\circ}$. 


\section{ELECTRONICS. RADIO ENGINEERING}
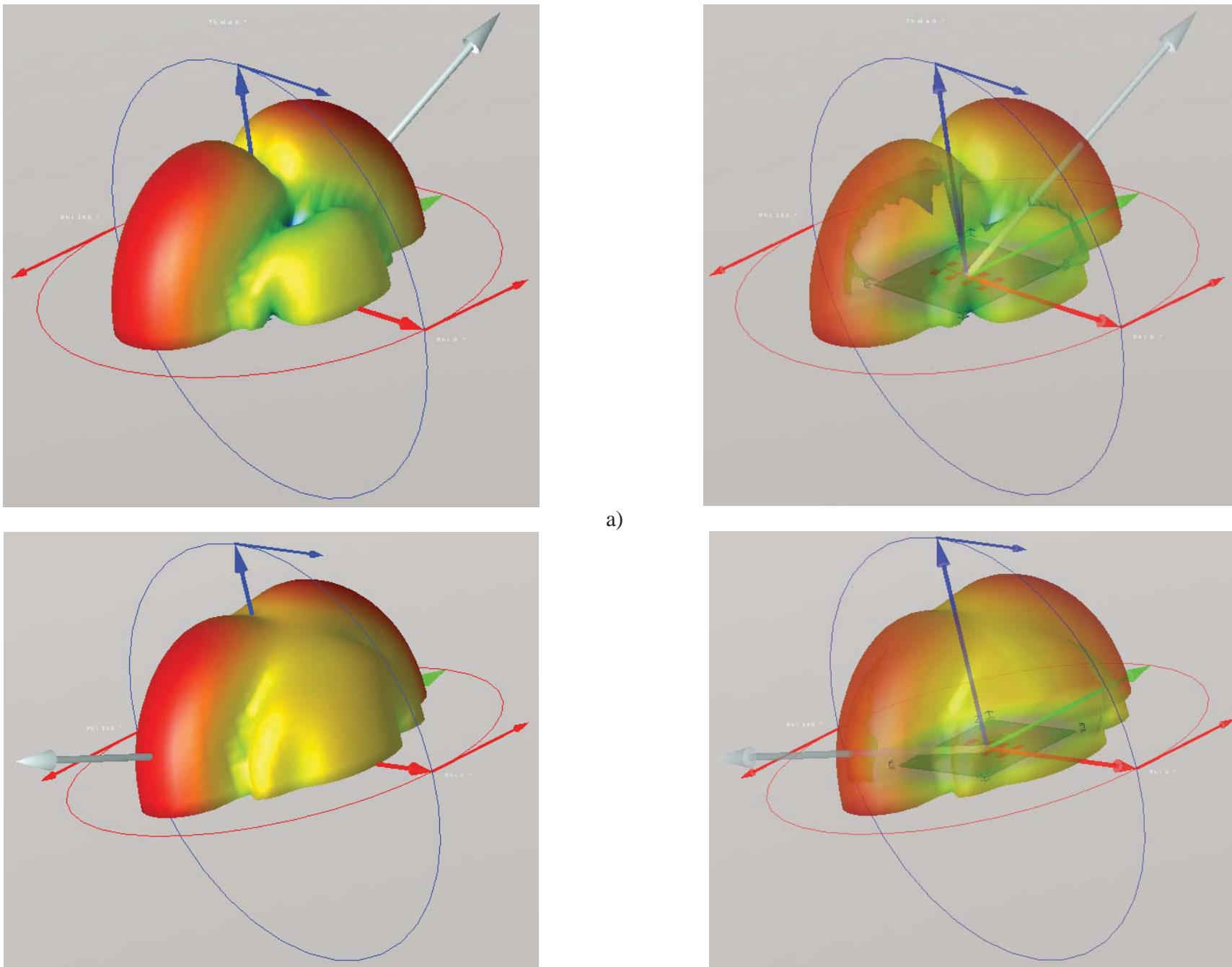

a)
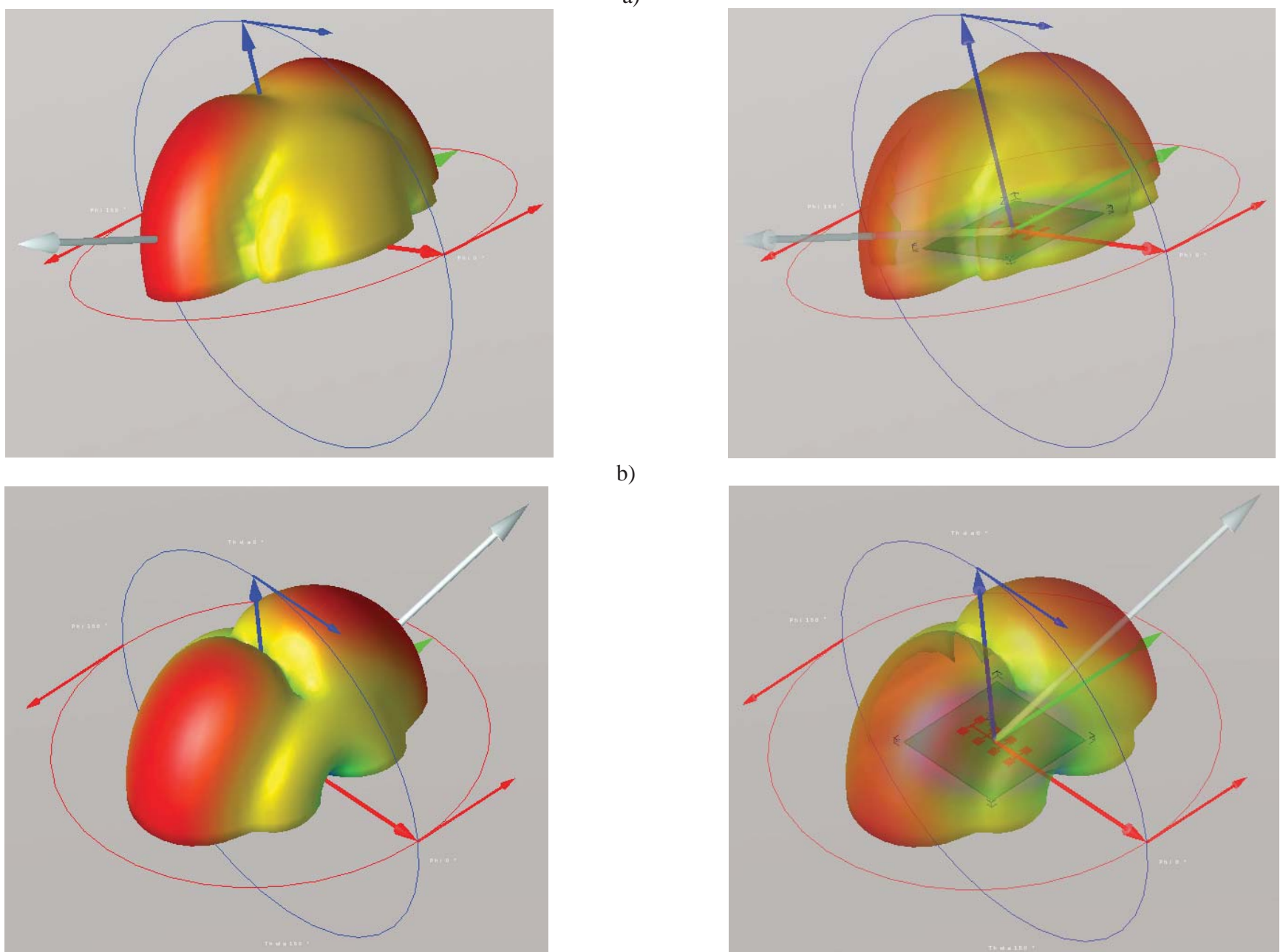

c)

Figure 9. Calculated 3D format gain of microstrip subarray of eight emitters simulation model, with power connection: a) the center of the subarray; b) through the shank, brought to the center of the subarray;

c) throu the shank, brought up on the side of the subarray 


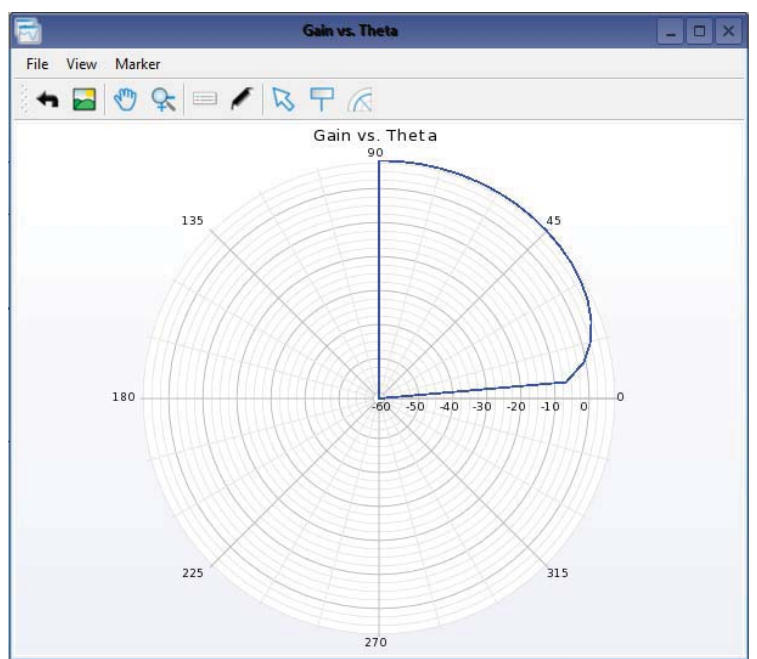

a)

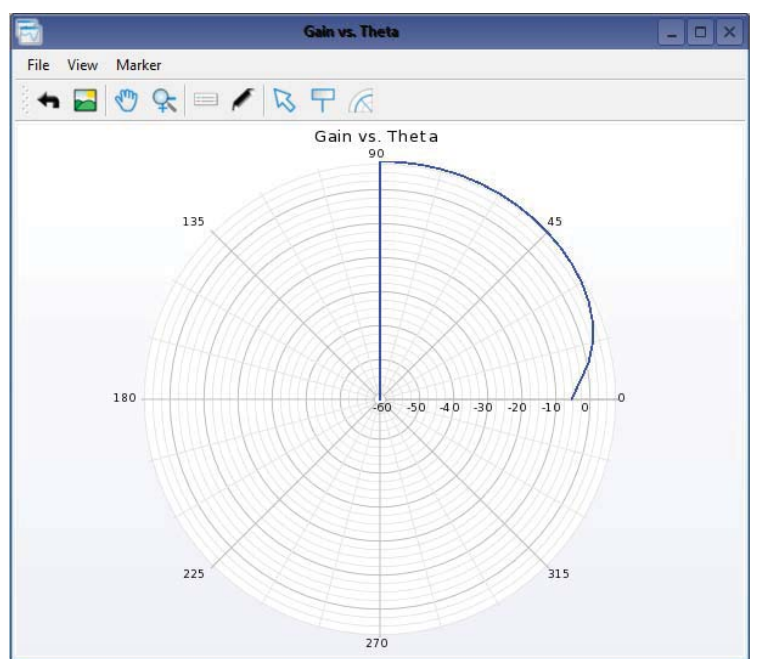

b)

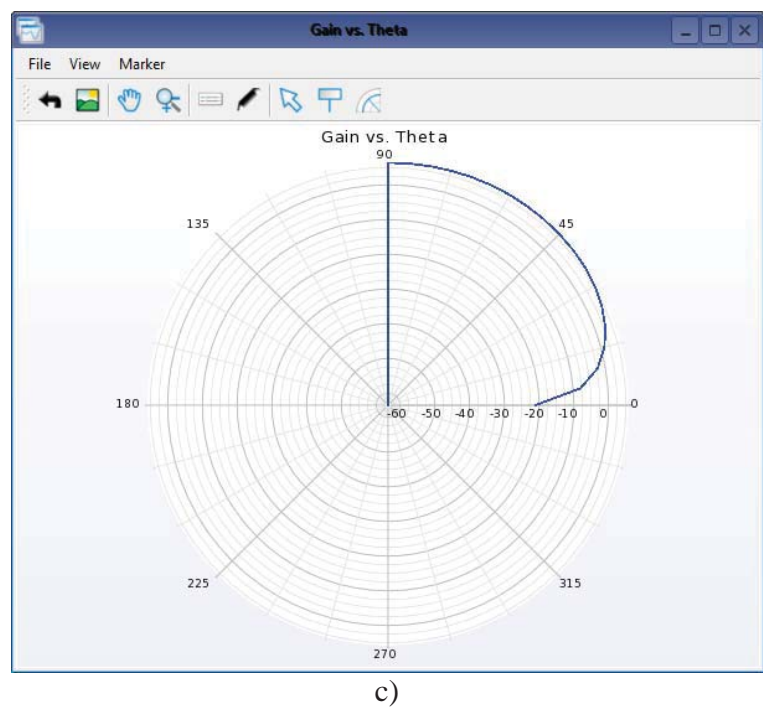

Figure 10. The gain of the simulation model of microstrip subarray of eight emitters simulation model, with power connection: a) in the center of the subarray; b) through the shank, brought to the center of the subarray; c) through the shank, brought up on the side of the subarray

From table 1 it can be noticed that for all subarrays, the resonant frequency (fr) lies within 6.2 GHz. All subarrays are rather narrow-band, their bandwidth $(\Delta \mathrm{F})$ was determined at the level of -3dB. The most broadband is the subarray with power supplied through the shank to the center of the subarray (Figure 1, b). However, the VSWR and efficiency of this subarray are much worse than the others. As a disadvantage of the subarray, with power supplied through a shank located on the side, an additional, pronounced, resonant frequency in the region of $5.85 \mathrm{GHz}$ can be noted. This subarray also has the lowest gain.

Based on the ratio of VSWR and efficiency, it is most preferable to use a subarray with power supplied to its center without additional shanks. This subarray also has the highest gain $=8.28$ $\mathrm{dB}$. However, in the future, in the manufacture of a full-scale model, difficulties may arise with the installation of the microwave connector.

This article discusses three simulation models of subarrays for microstrip PA with various options for their excitation. All subarrays have a radiation pattern of a special shape. After calculating the main characteristics, the issue of the most preferred organization of subarray power supply for the developed PA was solved. It is shown that in practice, the study of parameters and decision-making on the design of complex microwave devices, possibly without expensive field modeling.

\section{References}

1. Alexander Vasilchenko, Yves Scholz, Walter De Raad, Guy Vandenbosch, (2008). Qualitative assessment of computational methods of electrodynamics on the example of software products for highfrequency modeling of microstrip antennas. Technologies in the electronic industry. No. 3.

2. V.S. Bocharov, A.G. Generalov, E.V. Gadzhiev (2014). The choice of dielectric substrate for a microstrip antenna when constructing a miniature antenna, ed. Radio Engineering, Antennas Magazine, Issue No. 12.

3. O.I. Yastrebtsova (2014). Advantages of using materials as substrates for microstrip printed antennas, Materials of the international scientific and technical conference, INTERMATIC-2014, part 5.

4. Design of phased array antennas, ed. D.I. Voskresensky. Moscow: Radio Engineering, 2003.

5. B.A. Panchenko, E.I. Nefedov (1986). Microstrip antennas. Moscow: Radio and Communications. 


\section{ЗАВИСИМОСТЬ ЭЛЕКТРОДИНАМИЧЕСКИХ ХАРАКТЕРИСТИК ПОДРЕШЕТКИ МИКРОПОЛОСКОВОЙ ФАР ОТ СПОСОБА ПОДКЛЮЧЕНИЯ ПИТАНИЯ}

Уханов Евгений Валентинович, АО "Научно-исследовательский институт "Кулон", Москва, Россия, searif@уа.ru Терехин Роман Валерьевич, АО "Научно-исследовательский институт "Кулон", Москва, Россия, terekhin.r@gmail.com Косичкина Софья Романовна, АО "Научно-исследовательский институm "Кулон", Москва, Россия, sofkos@yandex.ru Стрыгин Константин Вячеславович, АО "Научно-исследовательский институт "Кулон", Москва, Pocсия, kstrygin@gmail.com Сюкиева Екатерина Викторовна, АО "Научно-исследовательский институт "Кулон", Москва, Poсcия, eksyukieva@gmail.com

\section{Аннотация}

В антенных системах различного назначения широко используется СВЧ-техника в микрополосковом исполнении. Активное использование фазированных антенных решеток (ФАР) данного типа заставляет разработчиков всего мира икать различные варианты их построения. Для улучшения отдельных характеристик, в частности расширения угла сканирования, а так же оптимизации конфигурации возбуждения ФАР, в них используют подрешетки, объединяющие заданное количество элементов всей решетки. В данной работе рассматривались различные варианты построения подрешеток микрополосковых ФАР выполненных на однородной подложке из высокочастотного ламината GIL_GML 1000, в частности, различные способы их возбуждения. С помощью современной, точной среды 3D электродинамического моделирования и анализа ВЧ-устройств исследовались изменения электродинамических характеристик имитационной модели многоэлементной подрешетки микрополосковой ФАР, в зависимости от способа организации возбуждения. Для каждой имитационной модели приведены результаты расчета коэффициента отражения (параметр SII) в зависимости от частотного диапазона, рассчитан коэффициент усиления в формате 3D, а так же в полярной системе координат.

Ключевые слова: фазированная антенная решётка, подрешетка, прямоугольный излучатель, коэффициент излучения, резонансная частота, ширина полосы.

\section{Литература}

І. Александр Васильченко, Ив Схольи, Вальтер Де Раад, Ги Ванденбош. Качественная оценка вычислительных методов электродинамики на примере программных продуктов для высокочастотного моделирования микрополосковых антенн // Технологии в электронной промышленности. №3. 2008.

2. Бочаров В.С., Генералов А.Г., Гаджиев Э.В. Выбор диэлектрика подложки микрополосковой антенны при построении миниатюрной антенны // Антенны, №12, 2014.

3. Ястребиова О.И. Преимущества использования материалов в качестве подложек для микрополосковых печатных антенн, Материалы международной научно-технической конференции, INTERMATIC-20I4, часть 5.

4. Проектирование фазированных антенных решеток, под ред. Д.И. Воскресенского. М.: Радиотехника, 2003.

5. Панченко Б.А., Нефедов Е.И. Микрополосковые антенны, М.: Радио и связь, 1986.

Информация об авторах:

Уханов Евгений Валентинович, к.т.н., доцент, начальник отдела, АО "Научно-исследовательский институт "Кулон", Москва, Россия Терехин Роман Валерьевич, старший инженер, АО "Научно-исследовательский институт "Кулон", Москва, Россия Косичкина Софья Романовна, инженер, АО "Научно-исследовательский институт "Кулон", Москва, Россия Стрыгин Константин Вячеславович, инженер, АО "Научно-исследовательский институт "Кулон", Москва, Россия Сюкиева Екатерина Викторовна, инженер, АО "Научно-исследовательский институт "Кулон", Москва, Россия 